\title{
PERAN ETIKA AUDITOR TERHADAP INDEPENDENSI, KOMPETENSI, DAN PENGALAMAN KERJA DENGAN KUALITAS AUDIT
}

\author{
Farida Ariyani ${ }^{1)}$, Alfiyani Nur Hidayanti ${ }^{2)}$ \\ Program Studi Akuntansi Fakultas Ekonomi dan Bisnis Universitas Muria Kudus \\ E-mail: ariyani224@gmail.com ${ }^{1}$ \\ alfiyani.nur@umk.ac.id ${ }^{2}$
}

\begin{abstract}
ABSTRAK
Penelitian ini bertujuan untuk menguji apakah pengaruh independensi, kompetensi, dan pengalaman kerja terhadap kualitas audit dengan etika auditor sebagai variabel moderasi. Populasi penelitian yang digunakan adalah Kantor Akuntan Publik yang berada di Jawa Tengah. Metode pengambilan sampel yang digunakan adalah metode Convinience sampling.Banyaknya responden yang digunakan dalam penelitian ini berjumlah 78 sampel yang mempunyai kriteria. Teknik analisis data yang digunakan adalah Moderated Regression Analysis (MRA). Hasil penelitian menunjukkan variabel independensi dan pengalaman kerja tidak berpengaruh terhadap kualitas audit, variabel kompetensi berpengaruh negatif terhadap kualitas audit. Interaksi variabel independensi dan etika auditor tidak berpengaruh terhadap kualitas audit, interaksi variabel kompetensi dan etika auditor berpengaruh positif terhadap kualitas audit, Interaksi variabel pengalaman kerja dan etika auditor tidak berpengaruh terhadap kualitas audit
\end{abstract}

Kata kunci : Independensi, Kompetensi, Pengalaman Kerja, Etika Auditor, dan Kualitas Audit.

\section{ABSTRACT}

This study aims to test whether the influence of independence, competence, and work experience on audit quality with auditor ethics as a moderation variable. Research population used is public accountant office located in central java. Sampling method used is convinience sampling method. The number of respondents used in this study to 78 samples having criteria. The data analysis technique used is Moderated Regression Analysis (MRA). The result of the research shows that the independence and work experience does not effect on the audit quality, the competence variable is negative effect to audit quality. The interaction of the independence variable and auditor ethics does not affect the audit quality, the competence interaction and the auditor ethics have a possitive influence on audit quality, the interaction of the work experience variable and auditor ethics does not affect the audit quality.

Keywords : Independence, Competence, Work Experience, Auditor Ethics, And Audit Quality.

\section{PENDAHULUAN}

Perkembangan dunia bisnis yang semakin pesat dan meningkat mengakibatkan persaingan dan permasalahan yang dihadapi perusahaan semakin kompleks. Hal inilah yang menyebabkan jasa audit akuntan publik semakin dibutuhkan. Karena hasil audit atas laporan 
keuangan tersebut dibutuhkan oleh pihak investor atau pihak yang berkepentingan lainya dalam pengambilan keputusan. Jasa audit akuntan publik dibutuhkan oleh publik atau pengguna laporan keuangan, hal ini disebabkan untuk menentukan keandalan pertanggungjawaban keuangan yang disajikan oleh manajemen dalam laporan keuangan (Uli, 2016).

Pada sebuah kasus tahun 2011, yaitu sebuah kasus kantor akuntan mitra Ernest dan Young (EY) indonesia yang didenda oleh AS karena memberikan pernyataan laporan hasil audit dengan status wajar tanpa pengecualian. Public Company Accounting Oversight Board (PCAOB) mengenakan denda UU\$ 1 juta dan juga memberikan sanksi kepada dua auditor Ernest dan Young (EY) yang terlibat dalam audit pada 2011. Dalam ketergesaan mereka atas mengeluarkan laporan audit untuk kliennya, Ernest dan Young (EY) dan dua mitranya lalai dalam menjalankan tugas dan fungsinya memperoleh bukti audit yang cukup.

Oleh karena itu seorang auditor dalam menjalankan tugas profesinya harus berpedoman pada standar audit yang telah ditetapkan oleh Institut Akuntan Publik Indonesia (IAPI), yaitu standar pekerjaan lapangan, standar umum, dan standar pelaporan.Dalam literatur akuntansi, independensi adalah bebas dari pengaruh, tidak dikendalikan oleh pihak lain, tidak tergantung pada orang lain (Mulyadi dan Puradireja, 2002: 26). Faktor lain selain independensi yang dapat mempengaruhi kualitas audit yaitu kompetensi. Menurut Lee dan Stone (1995) mendefinisikan kompetensi sebagai keahlian yang cukup yang secara eksplisit dapat digunakan untuk melakukan audit secara objektif. Faktor ketiga yang mempengaruhi kualitas audit adalah pengalaman kerja seorang auditor. Pengetahuan auditor akan semakin bertambah seiring dengan pengalaman melakukan tugas audit. Standar Profesional Akuntan Publik (SPAP, 2001) paragraf ketiga SA seksi 210 menyatakan "Dalam melaksanakan audit untuk sampai pada suatu pernyataan pendapat, auditor harus senantiasa bertindak sabagai seorang ahli dalam bidang akuntansi dan bidang auditing”. Keahlian ini dapat dicapai melalui pendidikan formal yang akan dikembangkan melalui pengalaman dalam tugas pengauditan.

Penelitian ini merupakan replikasi dari peneliti Darayasa dan Wisadha (2016).Perbedaan penelitian ini dari penelitian sebelumnya adalah variabel yang digunakan pada penelitian ini bertambah yaitu bukan hanya kompetensi dan independensi melainkan juga pengalaman kerja karena auditor yang memiliki pengalaman kerja yang baik akan mampu menyelesaikan pekerjaan secara cermat dan teliti sehingga kedua faktor tersebut dapat 
mempengaruhi kualitas audit yang dihasilkan Darayasa dan Wisadha (2016). Selain itu adapun perbedaan objek penelitian ini adalah Kantor Akuntan Publik yang ada di Jawa Tengah.

\section{TINJAUAN PUSTAKA}

\section{Teori Keagenan}

Teori keagenan yang dikembangkan oleh Jensen dan Meckling (1976) menyatakan bahwa teori keagenan atau agencytheory ini menjelaskan hubungan keagenan sebagai suatu kontrak kerjasama yang mana satu atau lebih prinsipal menggunakanorang lain atau agen untuk menjalankan aktivitas perusahaan. Prinsipal ingin mengetahui segala informasi termasuk aktifitas manajeman, yang terkait dengan segala informasi termasuk aktifitas manajemen, yang terkait dengan investasi atau dananya dalam perusahaan.Hal ini dilakukan dengan meminta laporan pertanggungjawaban dari agen (manajemen).Berdasarkan laporan tersebut, prinsipal dapat menilai kinerja manajemen.Namun yang seringkali terjadi adalah kecenderungan manajemen untuk melakukan tindakan yang membuat laporannya terlihat baik, sehingga kinerjanya dianggap baik.Untuk meminimalkan kecurangan tersebut dan agar manajemen lebih dapat dipercaya, maka diperlukan pengujian.Pengujian tersebut hanya dapat dilakukan oleh pihak ketiga yaitu auditor independen.

\section{Kualitas Audit}

De Angelo (1981) mendefinisikan kualitas audit sebagai probabilitas dimana seorang auditor menemukan dan melaporkan tentang adanya suatu pelanggaran dalam sistem akuntansi kliennya. Hasil penelitiannya menunjukkan bahwa KAP yang besar akan berusaha untuk menyajikan kualitas audit yang lebih besar dibandingkan dengan KAP yang kecil. Deis dan Giroux (1992) melakukan penelitian tentang empat hal yang dianggap mempunyai hubungan dengan kualitas audit yaitu (1) lama waktu auditor telah melakukan pemeriksaan terhadap suatu perusahaan (tenure), semakin lama seorang auditor telah melakukan audit pada klien yang sama maka kualitas audit yang dihasilkan akan semakin rendah, (2) jumlah klien,semakin banyak jumlah klien maka kualitas audit akan semakin baik karena auditor dengan jumlah klien yang banyak akan berusaha menjaga reputasinya, (3) kesehatan keuangan klien, semakin sehat kondisi keuangan klien maka akan ada kecenderungan klien tersebut untuk menekan auditor agar tidak mengikuti standar, dan (4) review oleh pihak ketiga, kualitas 
audit akan meningkat jika auditor tersebut mengetahui bahwa hasil pekerjaannya akan direview oleh pihak ketiga.

\section{Independensi}

Ada 3 pasal yang mengatur kepribadian akuntan publik yang pada dasarnya semua pasal tersebut mengatur independensi dan objektivitas akuntan tersebut.Independensi berarti bebas dari pengaruh, tidak dikendalikan oleh pihak lain, tidak tergantung pada orang lain (Mulyadi dan Puradireja, 2002: 26).Akuntan publik yang independen adalah akuntan yang tidak terpengaruh dan tidak dipengaruhi oleh berbagai kekuatan yang berasal dari luar diri akuntan dalam mempertimbangkan fakta yang dijumpainya dalam pemeriksaan.

\section{Kompetensi}

Menurut kamus Kompetensi LOMA (1998) dalam Aprianti (2010) kompetensi didefinisikan sebagai aspek-aspek pribadi dari seorang pekerja yang memungkinkan dia untuk mencapai kinerja superior. Aspek-aspek pribadi ini mencakup sifat, motif-motif, sistem nilai, sikap, pengetahuan dan ketrampilan dimana kompetensi akan mengarahkan tingkah laku, sedangkan tingkah laku akan menghasilkan kinerja. Trotter (1986) mendefinisikan bahwa seorang yang kompeten adalah orang yang dengan ketrampilannya mengerjakan pekerjaan dengan mudah, cepat, intuitif dan sangat jarang atau tidak pernah membuat kesalahan.

\section{Pengalaman Kerja}

Pengalaman auditor yaitu kegiatan melakukan audit laporan keuangan baik dari segi lamanya waktu maupun banyaknya penugasan yang pernah ditangani. Bahan Tubbs (1992) mengemukakan bahwa auditor yang berpengalaman memiliki keunggulan dalam mendeteksi kesalahan, memahami kesalahan secara akurat, serta mencari penyebab kesalahan, serta pemahaman yang lebih baik (Kusharyanti, 2002: 5).

\section{Etika Auditor}

Etika menurut Setyanugraha (2006) diartikan sebagai nilai-nilai dan norma-norma moral dalam suatu masyarakat. Dengan kata lain etika adalah hal yang boleh dan tidak boleh dilakukan. Etika juga berarti sebuah ilmu yang didalamnya mempelajari tentang hal yang baik maupun hal yang salah (buruk). Setiap manusia pasti akan melakukan sebuah kebaikan maupun kesalahan. Untuk itulah etika diperlukan untuk membentuk manusia yang berperilaku etis. 


\section{KERANGKA PEMIKIRAN}

Adapun kerangka pemikiran penelitian ini digambarkan pada model sebagai berikut.

\section{Gambar 1}

Kerangka pemikiran

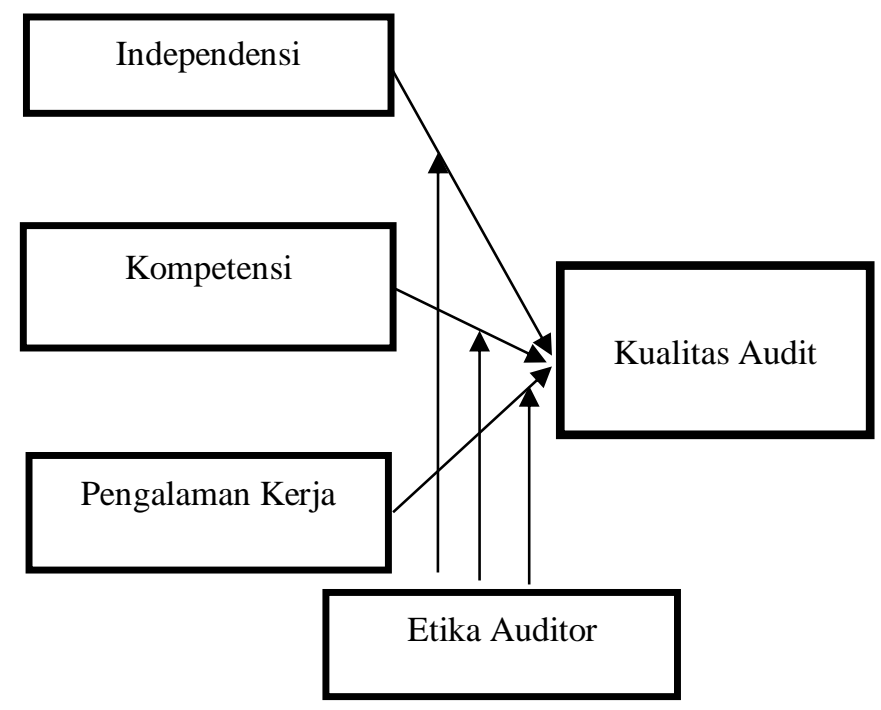

Sumber :I Made Darayasa (2016) dan I Gede Supartha Wisadha (2016) yang sudah dikembangkan.

\section{PENGEMBANGAN HIPOTESIS}

\section{Pengaruh Independensi terhadap Kualitas Audit}

Independensi mempunyai arti sikap mental yang bebas dari pengaruh, tidak dapat dikendalikan pihak lain, dan tidak tergantung oleh pihak lain. Independensi juga dapat diartikan sebagai kejujuran pada diri auditor dalam mempertimbangkan fakta dan pertimbangan yang objektif serta tidak memihak dalam menyatakan pendapatnya (Mulyadi, 2013). Dari penjelasan tersebut dapat disimpulkan bahwa independensi seorang auditor dalam menyatakan pendapatnya sangatlah penting untuk menentukan kualitas audit.

Penelitian yang dilakukan oleh Darayasa dan Wisadha (2016) menyatakan independensi berpengaruh signifikan positif terhadap kualitas audit.penelitian ini didukung dengan penelitian yang sebelumnya dilakukan oleh Singgih dan Bawono (2010) yang menyatakan bahwa independensi berpengaruh secara simultan terhadap kualitas audit. 
Berdasarkan teori dan penelitian sebelumnya memberikan bukti bahwa independensi dalam melakukan audit mempunyai dampak signifikan terhadap kualitas audit. Sehingga dapat dibuat hipotesis bahwa:

\section{$\mathrm{H}_{1}$ : Independensi berpengaruh positif terhadap Kualitas Audit}

\section{Pengaruh Kompetensi Terhadap Kualitas Audit}

Auditor yang berpendidikan tinggi akan mempunyai pandangan lebih luas mengenai berbagai hal. Auditor akan semakin mempunyai banyak pengetahuan mengenai bidang yang digelutinya, sehingga dapat mengetahui berbagai masalah secara lebih mendalam. Namun dengan ilmu pengetahuan yang cukup luas, auditor akan lebih mudah dalam mengikuti perkembangan yang semakin kompleks. Analisis audit kompleks membutuhkan spektrum yang luas mengenai keahlian, pengetahuan dan pengalaman (Meinhard et. All, 1987).

Aqmalia (2014) menyatakan bahwa kompetensi berpengaruh terhadap kualitas audit.Penelitian ini didukung dengan penelitian yang dilakukan oleh Marsellia,dkk (2009) yang menyatakan bahwa kompetensi berpengaruh signifikan terhadap kualitas audit. Berdasarkan teori dan penelitian sebelumnya yang memberikan bukti bahwa kompetensi mempunyai dampak signifikan terhadap kualitas audit. maka, dapat dibuat hipotesis bahwa :

\section{$\mathrm{H}_{2}$ : Kompetensi berpengaruh positif terhadap Kualitas Audit}

\section{Pengaruh Pengalaman Kerja Terhadap Kualitas Audit}

Kebanyakan orang memahami bahwa semakin banyak jumlah jam terbang seorang auditor, tentunya dapat memberikan kualitas audit yang lebih baik daripada seorang auditor yang baru memulai karirnya. Atau dengan kata lain auditor yang berpengalaman diasumsikan dapat memberikan kualitas audit yang lebih baik dibandingkan dengan auditor yang belum berpengalaman. Hal ini dikarenakan pengalaman akan membentuk keahlian seseorang baik secara teknis maupun secara psikis (Singgih dan Bawono, 2010).

Penelitian yang dilakukan oleh Futri dan Juliarsa (2014) menyatakan bahwa pengalaman kerja berpengaruh secara simultan terhadap kualitas audit. penelitian ini sesuai dengan penelitian yang dilakukan Wiratama dan Budiartha (2015) menyatakan pengalaman kerja berpengaruh positif signifikan terhadap kualitas audit. Berdasarkan penjelasan diatas dapat dikembangkan hipotesis sebagai berikut :

\section{$\mathrm{H}_{3}$ : Pengalaman Kerja berpengaruh positif terhadap Kualitas Audit}




\section{Interaksi Antara Independensi Dengan Etika Auditor Terhadap Kualitas Audit}

Ketika auditor dan manajemen tidak mencapai kata sepakat dalam aspek kinerja, maka kondisi ini mendorong manajemen untuk memaksa auditor melakukan tindakan yang melawan standar, termasuk dalam pemberian opini. Kondisi ini akan sangat menyudutkan auditor sehingga kemungkinan bahwa auditor akan melakukan apa yang diinginkan oleh manajemen. Tidak mudah menjaga tingkat independensi agar tetap sesuai dengan jalur yang seharusnya.Kerjasama dengan klien yang terlalu lama bisa menimbulkan kerawanan atas independensi yang dimiliki auditor. Belum lagi berbagai fasilitas yang disediakan klien selama penugasan audit untuk auditor. Apabila seorang auditor tidak memiliki etika yang baik bukan tidak mungkin auditor menjadi "mudah dikendalikan" klien karena auditor berada dalam posisi yang dilematis (Alim dkk, 2007).

Penelitian yang dilakukanWidyanto (2012) mengatakan bahwa interaksi independensi dan etika auditor berpengaruh terhadap kualitas audit. Ini didukung dengan penelitian yang dilakukan oleh Alim,dkk (2007) yang mengakatan bahwa interaksi independensi dan etika auditor berpengaruh signifikan terhadap kualitas audit.

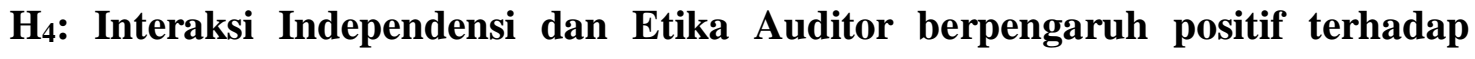 Kualitas Audit.}

\section{Interaksi Antara Kompetensi Dengan Etika Auditor Terhadap Kualitas Audit}

Seorang auditor yang memiliki kompetensi tinggi didalam melaksanakan audit akan selalu taat pada prinsip audit serta patuh terhadap kode etik yang berlaku untuk dapat menghasilkan kualitas audit yang tinggi. Seorang auditr dalam melaksanakan tugasnya harus berpedoman pada standar audit yang telah ditetapkan, yaitu standar umum, standar pekerjaan lapangan, dan standar pelaporan. Selain standar audit, auditor juga harus mematuhi kode etik profesi yang mengatur perilaku auditor dalam menjalankan praktik.

Penelitian yang dilakukan Ramadhani (2015) menyatakan bahwa interaksi kompetensi dan etika auditor berpengaruh signifikan terhadap kualitas audit. Hal ini dibuktikan dengan penelitian yang dilakukanoleh Saputra (2012) yang menyatakan etika audit dapar memoderasi secara kuat pengaruh kompetensi terhadap kualitas audit.

H5: Interaksi Kompetensi dan Etika Auditor berpengaruh positif terhadap Kualitas Audit 


\section{Interaksi Antara Pengalaman Kerja Dengan Etika Auditor Terhadap Kualitas Audit}

Berdasarkan teori keagenan auditor yang mempunyai pengalaman kerja lebih lama mempunyai perilaku etis dibanding auditor yang mempunyai pengalaman kerja yang singkat. Auditor yang memiliki pengalaman akan lebih bijaksana dalam menjalankan apa yang klien tugaskan kepadanya. Hal ini berarti bahwa semakin tinggi tingkat pengalaman auditor diikuti dengan etika auditor yang baik maka kualitas audit yang dihasilkan semakin baik.

Penelitian yang dilakukan oleh Samsi,dkk (2012) menyatakan bahwa interaksi pengalaman kerja dengan etika auditor berpengaruh terhadap kualitas hasil pemeriksaan. Dari penjelasan diatas dapat dikembangkan hipotesis sebagai berikut :

\section{$\mathrm{H}_{6}$ : Interaksi Pengalaman Kerja dan Etika auditor berpengaruh positif terhadap}

\section{Kualitas Audit}

\section{METODE PENELITIAN}

Penelitian ini menggunakan data primer.Populasi pada penelitian ini adalah seluruh Kantor Akuntan Publik di Jawa Tengah.Sampel dalam penelitian ini menggunakan conviniencesamplingyaitu sebanyak143 responden.

\section{Pengukuran Variabel}

a. Independensi (X1)

Untuk mengukur variabel yang locus of control melalui tanggapan responden digunakan skala likert 5 poin, yaitu 1= STS (sangat tidak setuju), 2= TS(tidak setuju), 3= $\mathrm{N}$ (netral), 4= S (setuju), dan 5= SS (sangat setuju) yang menggunakan jurnal dariAprianti (2010) dengan indikator tertentu.

b. Kompetensi (X2)

Variabel kompetensi diukur dengan menggunakan skala likert 5 point yaitu, $1=$ STS(sangat tidak setuju), 2= TS(tidak setuju), 3= N(netral), 4= S(setuju), dan 5= SS(sangat setuju) yang menggunakan jurnal dariAprianti (2010) dan dengan indikator.

c. Pengalaman Kerja(X3)

Untuk mengukur variabel pengalaman kerja yang diteliti melalui tanggapan dari responden digunakan skala likert 5 poin yaitu, $1=\operatorname{STS}($ sangat tidak setuju), $2=$ TS(tidak setuju), $3=\mathrm{N}($ netral), $4=\mathrm{S}($ setuju), dan $5=\mathrm{SS}$ (sangat setuju), yang menggunakan jurnal dari Agustina (2016)dengan indikator tertentu. 


\section{[ACCOUNTING GLOBAL JOURNAL] E ISSN}

d. Etika Auditor (Z)

Untuk mengukur variabel etika auditor yang diteliti melalui tanggapan dari responden digunakan skala likert 5 poin yaitu, $1=$ STS(sangat tidak setuju), $2=$ TS(tidak setuju), $3=$ $\mathrm{N}$ (netral), 4= S(setuju), dan 5= SS(sangat setuju), yang menggunakan jurnal dari Aprianti (2010) dengan indikator tertentu.

e. Kualitas Audit

Responden diminta memberikan jawaban pada pernyataan yang tersedia sesuai dengan penilaiannya. Skala pengukurannya adalah dengan menggunakan skala likert 5 poin, yaitu 1= STS (sangat tidak setuju), 2= TS (tidak setuju, 3= N (netral), 4= S (setuju) dan 5= SS (sangat setuju)yang menggunakan jurnal dari Aprianti (2010) dengan indikator tertentu.

\section{Uji Hipotesis}

Untuk mengukur variabel diatas menggunakan metode analisis regresi moderasi (MRA). Adapun persamaannya adalah sebagai berikut :

KA $=\alpha+\beta_{1}$ IND $+\beta_{2}$ KOM $+\beta_{3}$ PK $+\beta_{4}$ EA.IND $+\beta_{5}$ EA.KOM $+\beta_{6}$ EA.PK $+\varepsilon$

Dimana :
$\mathrm{KA}=$ Kualitas Audit
$\alpha \quad=$ Konstant
$\beta_{1}-\beta_{6}=$ Koefisien Regresi
IND = Independensi
$\mathrm{KOM}=$ Kompetensi
$\mathrm{PK}=$ Pengalaman Kerja
EA $=$ Etika Auditor
$\varepsilon=$ Error . 


\section{HASIL DAN PEMBAHASAN}

Berdasarkan hasil output SPSS 23, menunjukkan bahwa:

\begin{tabular}{|l|c|c|c|c|c|}
\hline \multirow{7}{*}{ Variabel } & \multicolumn{2}{|c|}{$\begin{array}{c}\text { Unstandardized } \\
\text { Coefficients }\end{array}$} & $\begin{array}{c}\text { Standa } \\
\text { rdized } \\
\text { Coeffi } \\
\text { cients }\end{array}$ & \multirow{2}{*}{$\mathrm{t}$} & \multirow{2}{*}{ Sig. } \\
\cline { 2 - 5 } & $\mathrm{B}$ & $\begin{array}{c}\text { Std. } \\
\text { Error }\end{array}$ & Beta & & \\
\hline (Constant) & $\begin{array}{c}19,11 \\
7\end{array}$ & 4,976 & & 3,842 &, 000 \\
\hline Independensi & 1,158 &, 715 &, 810 & 1,620 &, 110 \\
\hline Kompetensi & $-1,629$ &, 606 & -1.179 & $-2,688$ &, 009 \\
\hline $\begin{array}{l}\text { Pengalaman } \\
\text { Kerja }\end{array}$ & 1,669 &, 974 &, 868 & 1,713 &, 091 \\
\hline Ind*Etk &,- 042 &, 043 & $-1,249$ &,- 977 &, 332 \\
\hline Kom*Etk &, 098 &, 038 & 2,971 & 2,597 &, 011 \\
\hline PK*Etk &,- 077 &, 059 & $-1,302$ & $-1,297$ &, 199 \\
\hline
\end{tabular}

Sumber: Data Primer yang diolah, 2018.

Berdasarkan hasil perhitungan regresi yang telah diperoleh, maka dapat dibentuk persamaan regresi moderasi sebagai berikut:

$$
Y=19,117+1,158 X_{1}-1,629 X_{2}+1,669 X_{3}-0,042 X_{1} Z+0,098 X_{2} Z-0,077 X_{3} Z+e
$$

Berdasarkan persamaan diatas dapat dilakukan interprestasi sebagai berikut:

1. Nilai konstanta bernilai positif sebesar 19,117 menunjukkan bahwa apabila seluruh variabel independen dianggap konstan (0), maka nilai rata-rata kualitas audit adalah sebesar 19,117.

2. Independensi memiliki koefisien bertanda positif sebesar 1,158 artinya peningkatan independensi dalam kelipatan eksponensial diprediksi akan meningkatkan kualitas audit sebesar $115,8 \%$.

3. Kompetensi memiliki koefisien bertanda negatif sebesar -1,629 artinya peningkatan kompetensi dalam kelipatan eksponensial diprediksi akan menurunkan kualitas audit sebesar $-162,9 \%$.

4. Pengalaman kerja memiliki koefisien bertanda positif sebesar 1,669 artinya peningkatan pengalaman kerja dalam kelipatan eksponensial diprediksi akan meningkatkan kualitas audit sebesar $166,9 \%$. 
5. Interaksi independensi dengan etika auditor memiliki koefisien bertanda negatif sebesar -0,042 artinya peningkatan interaksi independensi dengan etika auditor dalam kelipatan eksponensial diprediksi akan menurunkankualitas audit sebesar -4,2\%.

6. Interaksi kompetensi dengan etika auditor memiliki koefisien bertanda positif sebesar 0,098 artinya peningkatan interaksi kompetensi dengan etika auditor dalam kelipatan eksponensial diprediksi akan meningkatkan kualitas audit sebesar 9,8\%.

7. Interaksi pengalaman kerja dengan etika auditor memiliki koefisien bertanda negatif sebesar -0,077 artinya peningkatan interaksi pengalaman kerja dengan etika auditor dalam kelipatan eksponensial diprediksi akan meningkatkan kualitas audit sebesar $7,7 \%$.

\section{V, KESIMPULAN}

Berdasarkan hasil pengujian hipotesis pertama $\left(\mathrm{H}_{1}\right)$ ditolak. Hal ini berarti bahwa semakin tinggi independensi seorang auditor maka semakin rendah kualitas audit yang dihasilkan. Berdasarkan hasil pengujian hipotesis kedua $\left(\mathrm{H}_{2}\right)$ ditolak karena arah yang berbeda. Hal ini berarti bahwa semakin tinggi kompetensi seorang auditor maka semakin rendah kualitas audit yang dihasilkan. Berdasarkan hasil pengujian hipotesis keetiga $\left(\mathrm{H}_{3}\right)$ ditolak. Hal ini berarti bahwa semakin tinggi pengalamaan kerja seorang auditor maka semakin rendah kualitas audit yang dihasilkan. Berdasarkan hasil pengujian hipotesis keempat $\left(\mathrm{H}_{4}\right)$ ditolak. Hal ini berarti bahwa semakin tinggi independensi diikuti dengan etika yang baik maka tidak mempengaruhi kualitas audit yang dihasilkan. Berdasarkan hasil pengujian hipotesis kelima $\left(\mathrm{H}_{5}\right)$ diterima. Hal ini berarti bahwa semakin tinggi kompetensi diikuti dengan etika auditor yang baik maka semakin baik kualitas audit yang dihasilkan. Berdasarkan hasil pengujian hipotesis keenam $\left(\mathrm{H}_{6}\right)$ ditolak. Hal ini berarti bahwa semakin tinggi pengalaman kerja diikuti dengan etika auditor yang baik maka tidak mempengaruhi kualitas audit yang dihasilkan.

\section{Keterbatasan Penelitian}

Penelitian ini terdapat beberapa keterbatasan yaitu sebagai berikut:

1. Dalam penelitian ini hanya menggunakan kuesioner sebagai instrumen, sehingga masih ada kemungkinan kelemahan yang diperoleh, misalnya jawaban yang tidak cermat dan pertanyaan yang kurang dipahami oleh responden. 
2. Variabel kompetensi dalam penelitian ini hanya mengunakan indikator pengetahuan dan psikologi, sehingga belum dapat digunakan dalam menentukan kualitas audit dengan didapatkanya hasil yang negatif.

\section{Saran}

Bagi Kantor Akuntan Publik di wilayah Jawa Tengah disarankan agar lebih meningkatkan independensi, kompetensi, dan pengalaman kerja, serta menjaga etika seorang auditor karena faktor tersebut telah terbukti memberikan dampak positif untuk meningkatkan kualitas audit. Peneliti selanjutnya dapat menambahkan atau menguji variabel lain yang dapat mempengaruhi kualitas audit seperti akuntabilitas karena akuntabilitas merupakan hal yang sangat penting yang harus dimiliki oleh seorang auditor dalam melaksanakan pekerjaannya. Hal ini sesuai dengan penelitian yang dilakukan (Widiyanto, 2012)

\section{DAFTAR PUSTAKA}

Agustina. 2016. "Pengaruh Independensi, Pengalaman Kerja, Dan Fee Audit Terhadap Kualitas Audit (Studi Empiris Pada KAP Di Makassar)”. Skripsi. Fakultas Ekonomi Dan Bisnis UNHAS. Makassar.

Alim, Nizarul, Trisni Hapsari, dan Liliek Purwanti. 2007. Pengaruh Kompetensi dan Independensi Terhadap Kualitas Audit dengan Etika Auditor Sebagai Variabel Moderasi.Simposium Nasional Akuntansi X. Makassar.

Aprianti, Deva. 2010. "Pengaruh Kompetensi, Independensi, dan Keahlian Profesional terhadap Kualitas Audit dengan Etika Auditor sebagai Variabel Moderasi (Studi Empiris pada Kantor Akuntan Publik di Wilayah Jakarta Selatan)". Skripsi.Fakultas Ekonomi Akuntansi UIN Syarif Hidayatullah. Jakarta.

Aqmalia, Intania Nur. 2014. "Pengaruh Kompetensi Dan Independensi Terhadap Kualitas Audit Dengan Etika Auditor Sebagai Variabel Moderating (Studi Empiris Pada Auditor Kantor Akuntan Publik di Wilayah Surakarta dan Yogyakarta)". Naskah Publikasi. Fakultas Ekonomi Program Studi Akuntansi UMS. Surakarta.

Bustami, Afif. 2013. "Pengaruh Independensi, Akuntabilitas Dan Profesionalisme Auditor Terhadap Kualitas Audit (Studi Empiris Pada Kantor Akuntan Publik Di Dki Jakarta)”.'Skripsi.Fakultas Ekonomi Dan Bisnis UIN Syarif Hidayatullah. Jakarta.

Darayasa, I Made dan I Gede Supartha Wisadha. 2016. "Etika Auditor Sebagai Pemoderasi Pengaruh Kompetensi dan Independensi Pada Kualitass Audit Di Kota Denpasar". EJurnal Akuntansi Univesitas Udayana Vol.15.1.April (2016): 142-170. Fakultas Ekonomi dan Bisnis UNUD.Bali.

De Angelo, Linda Elizabeth. 1981. “Auditor Size and Audit Quality”. Journal of accounting \& Economic. 
Deli, Leni dkk. 2015. Faktor-Faktor Yang Mempengaruhi Kualitas Audit Dengan Etika Auditor Sebagai Moderating Variabel. Jurnal Riset Akuntansi Dan Bisnis Volume 15 No.1.Fakultas Ekonomi Univesitas Muhammadiyah Sumatra Utara.

Direktori Institut Akuntan Publik Indonesia.http:www.iapi.or.id diakses pada tanggal 10 Juni 2017.

Futri, Putu Septiani dan Gede Juliarsa. 2014. "Pengaruh Independensi, Profesionalisme, Tingkat Pendidikan, Etika Profesi, Pengalaman, Dan Kepuasan Kerja Auditor Pada Kualitas Audit Kantor Akuntan Publik Di Bali”. E-Jurnal. Akuntansi Universitas Udayana. Bali.

Ghozali, Imam. 2013. "Aplikasi Analisis Multivariate Dengan Program IBM SPSS 21". Undip. Semarang.

Harjanto, Atta Putra. 2014. "Pengaruh Kompetensi, Independensi, Objektifitas, Akuntabilitas dan Integritas Terhadap Kualitas Audit dengan Etika Auditor Sebagai Variabel Moderasi (Studi Empiris KAP di Semarang)". Skripsi.Fakultas Ekonomika dan Bisnis Universitas Diponegoro. Semarang.

Ikatan Akuntan Indonesia-Komparrtemen Akuntan Publik (IAI-KAP). 2001. Standar Profesional Akuntan Publik. Jakarta. Salemba Empat.

Irianto, Agus. (2010). Statistika Konsep, Dasar, Aplikasi, dan Pengembangannya. Jakarta: Kencana Prenada Media Group.

Kharismatuti, Norma.2012. "Pengaruh Kompetensi dan Independensi terhadap Kualitas Audit dengan Etika Auditor sebagai Variabel Moderasi (Studi Empiris pada Internal Auditor BPKP DKI Jakarta)’.Skripsi. Fakultas Ekonomi Universitas Diponegoro. Semarang.

Kuncoro, Mudrajad. 2009. “Metode Riset Untuk Bisnis \& Ekonomi Edisi 3”. Fakultas Ekonomika dan Bisnis Universitas Gadjah Mada. Yogyakarta.

Lee, Tom dan Mary Stone. 1995. "Competennce and Independence: The Congenial Twins Of Auditing?". Journal Of Business Finance and Accounting. 22(8).(December). Pp 11691177.

Marsellia, dkk. 2012. "Pengaruh Kompetensi dan Independensi Terhadap Kualitas Audit Dengan Etika Auditor Sebagai Variabel Moderator (Studi Empiris Pada Auditor Di KAP Big Four Jakarta)". Program Studi Akuntansi. Institut Bisnis dan Informatika Indonesia (IBII).

Mulyadi. 1992. “Pemeriksaan Akuntan Edisi Ke 4”.STIE YKPN.Yogyakarta.

Samsi, Nur, dkk. 2012. "Pengaruh Pengalaman Kerja, Independensi, Dan Kompetensi Terhadap Kualitas Hasil Pemeriksaan Dengan Kepatuhan Etika Auditor Sebagai Variabel Pemoderasi”. Jurnal Ilmu \& Akuntansi Vol.1 No.12.Sekolah Tinggi Ilmu Ekonomi Indonesia. Surabaya. 
Singgih, Elisha Muliani dan Icuk Rangga Bawono.2010.Pengaruh Independensi, Pengalaman, Due Proffesional Care, dan Akuntabilitas terhadap Kualitas Audit.Simposium Nasional Akuntansi XIII.Purwokerto.

Uli, AprillaShinta. 2016 .Pengaruh Locus of Control, Pengalaman Auditor, Dan EtikaProfesionalTerhadapPerilaku Auditor DalamSituasiKonflik Audit. JomFekon Vol. 3 No. 1(Februari).

Widyanto, Aris. 2012. "Pengaruh Independensi, Due Professional Care Dan Akuntabilitas Terhadap Kualitas Audit Dengan Etika Profesi Sebagai Variabel Mooderating (Studi Empiris Pada Auditor Kantor Akuntan Publik di Wilayah Surakarta dan Yogyakarta)".Naskah Publikasi.Fakultas Ekonomi Program Studi Akuntansi UMS. Surakarta.

Wiratama, William Jefferson dan Ketut Budiartha. 2015. "Pengaruh Independensi, Pengalaman Kerja, Due Professional Care Dan Akuntabilitas Terhadap Kualitas Audit". E-Jurnal. Fakultas Ekonomi Universitas Udayana. Bali. 